\begin{tabular}{|l|l|l|l|l|l|}
\hline JRL & Vol.13 & No.1 & Hal. 18 - 34 & $\begin{array}{c}\text { Jakarta, } \\
\text { Juni 2020 }\end{array}$ & $\begin{array}{r}\text { p-ISSN : 2085.38616 } \\
\text { e-ISSN : 2580-0442 }\end{array}$ \\
\hline
\end{tabular}

\title{
FITOREMEDIASI CEMARAN HIDROKARBON MINYAK BUMI MENGGUNAKAN POTENSI TUMBUHAN TYPHA ANGUSTIFOLIA
}

\author{
Tuti Suryati \\ Pusat Teknologi Lingkungan, BPPT \\ E-mail : tuti.suryati@bppt.go.id
}

\begin{abstract}
Abstrak
Pencemaran minyak bumi di lahan basah (perairan) akan lebih membahayakan karena penyebarannya yang lebih cepat meluas sehingga akan lebih cepat pula mencapai sumber-sumber air yang dibutuhkan untuk kehidupan. Tanaman Typha angustifolia merupakan salah satu tanaman lahan basah (perairan) yang telah digunakan untuk fitoremediasi logam berat dan limbah organik. Penelitian yang dilakukan adalah untuk mengkaji potensi tumbuhan tersebut untuk digunakan dalam fitoremediasi cemaran hidrokarbon minyak bumi. Tanaman Typha angustifolia ditanam dalam media lumpur yang mengandung cemaran hidrokarbon minyak bumi (crude oil) pada kadar $0 \mathrm{~kg}, 0,5 \mathrm{~kg}, 1 \mathrm{~kg}$ dan $2 \mathrm{~kg}$ selama pemaparan dua puluh minggu. Parameter yang dianalisis meliputi pertumbuhan tanaman dan kadar total petroleum hydrocarbon (TPH). Hasil penelitian menunjukkan bahwa tanaman Typha angustifolia dapat tumbuh pada media yang mengandung cemaran minyak bumi sampai kadar TPH awal 11,92\%. Setelah 20 minggu kadar TPH dalam media yang ditanami lebih rendah daripada media yang tidak ditanami (kontrol). Persentase penurunan TPH tertinggi dicapai pada media dengan penambahan minyak bumi 0,5 kg (kadar TPH awal 4,42\%), dengan penurunan TPH sebesar 42,6\%. Hasil penelitian ini menunjukkan bahwa tanaman Typha angustifolia potensial dapat digunakan untuk fitoremediasi cemaran hidrokarbon minyak bumi.
\end{abstract}

Kata kunci : Typha angustifolia, cemaran hidrokarbon minyak bumi, fitoremediasi 


\title{
PHYTOREMEDIATION OF PETROLEUM HYDROCARBON CONTAMINATION USING POTENTIAL PLANTS OF TYPHA ANGUSTIFOLIA
}

\begin{abstract}
Petroleum pollution in wetlands (water) will be more dangerous because its spread is expanding faster so that it will also be quicker to reach the sources of water needed for life. Typha angustifolia plant is one of the wetland plants (waters) that have been used for phytoremediation of heavy metals and organic waste. The research conducted is to examine the potential of these plants to be used in phytoremediation of petroleum hydrocarbon contamination. Typha angustifolia plants are planted in mud media containing crude oil hydrocarbon contamination at levels of $0 \mathrm{~kg}, 0.5 \mathrm{~kg}, 1 \mathrm{~kg}$, and $2 \mathrm{~kg}$ during twenty weeks of exposure. Parameters analyzed include plant growth and total petroleum hydrocarbon (TPH) content. The results showed that Typha angustifolia plants can grow on media containing petroleum contamination to an initial TPH level of 11.92\%. After 20 weeks the TPH level in the planted media is lower than that of the unplanted (control) media. The highest TPH reduction percentage was achieved in the media with the addition of $0.5 \mathrm{~kg}$ petroleum (initial TPH content $4.42 \%$ ), with a TPH reduction of $42.6 \%$. The result of this study indicates that the Typha angustifolia plant can potentially be used for phytoremediation of petroleum hydrocarbon contamination.
\end{abstract}

Keywords : Typha angustifolia, petroleum hydrocarbon contamination, phytoremediation 


\section{PENDAHULUAN}

Pencemaran lingkungan oleh minyak bumi dapat berpindah dari tanah ke air tanah, danau, rawa, sungai atau sumber air yang menyediakan air bagi kebutuhan domestik maupun industri, sehingga menjadi masalah serius bagi lingkungan. Jika minyak tertumpah ke lingkungan aquatik (maritime dan air tawar), dapat menyebabkan kerusakan pada organisma hidup yang ada di dalam air. Dampak pencemaran tumpahan minyak ke lingkungan aquatik, akan lebih membahayakan karena kecepatan penyebaran tumpahan minyak tersebut lebih cepat dibandingkan tumpahan di darat. Tumpahan minyak yang terjadi di lingkungan aquatik (perairan), dapat dengan cepat bergerak menyebar dan merubah struktur fisik dan kimiawinya. Jika proses ini terjadi, tumpahan minyak ini mengancam organisma di dalam air yang pada akhirnya merusak rantai makanan dari tingkat yang paling bawah yaitu plankton (USEPA, 1999).

Tumpahan minyak secara umum, dapat menyebabkan berbagai kerusakan pada tanaman rawa. Cemaran tersebut ditemukan dapat mengurangi pertumbuhan, laju fotosintesis, tinggi batang, kepadatan, dan biomassa di atas tanah tanaman Spartina alterniflora dan S. Patens dan dapat menyebabkan kematian tanaman tersebut (Krebs dan Tamer, 1981 dalam Onwurah dkk. 2007). Menurut Connel dan Miller (1995), senyawa hidrokarbon minyak bumi memiliki karakteristik toksik, karsinogenik, mutagenik, dan berpotensi untuk terakumulasi dalam rantai makanan dan jaringan lemak manusia yang dapat menyebabkan terjadinya keracunan saraf / neurotoxicity. Tingkat keparahan dari dampak oil spill ini tergantung pada banyak faktor, termasuk karakteristik minyak itu sendiri, suhu air dan cuaca. Beberapa jenis flora / fauna memiliki tingkat kepekaan berbeda terhadap oil spill ini (USEPA, 1999).

Menurut Badan Perlindungan Lingkungan Amerika (USEPA, 2011), pelepasan cemaran minyak bumi ke lingkungan akan mengancam kesehatan dan keselamatan masyarakat dengan mencemari air minum, menyebabkan bahaya kebakaran dan ledakan, berkurangnya kualitas udara dan air, merusak pertanian dan perkebunan dan lainlain. Setelah tanah tercemar oleh hidrokarbon minyak bumi (PHC), pemulihan mungkin memakan waktu beberapa tahun (Adipah, 2019). Berdasarkan Peraturan Pemerintah no. 101 tahun 2014 tentang Pengelolaan Limbah Bahan Berbahaya dan Beracun pada Lampiran 1 Tabel 1 Daftar Limbah B3 dari sumber yang tidak spesifik disebutkan bahwa limbah dan / atau tumpahan minyak bumi - Hydrocarbon Oil Spill - termasuk ke dalam golongan limbah bahan berbahaya dan beracun (B3), karena memiliki karakter / sifat mudah terbakar dan toksik. Jika tumpah ke lingkungan akan mencemari habitat alamiah di lokasi tersebut, berbahaya dan beracun bagi flora dan fauna, dan bahkan dalam tingkatan tertentu berbahaya juga bagi manusia.

Untuk pemulihan lahan yang terkontaminasi dapat digunakan proses fisik, kimia, dan biologis. Salah satu metode untuk pemulihan lahan terkontaminasi secara biologis adalah dengan menggunakan tanaman yang disebut fitoremediasi. Secara rinci fitoremediasi adalah penggunaan tanaman, termasuk pohon-pohonan, rumput-rumputan dan tanaman air, untuk menghilangkan atau 
memecahkan

bahan-bahan

berbahaya baik organik maupun anorganik dari lingkungan seperti tanah, sludge, kolam, maupun sungai. Fitoremediasi dapat diaplikasikan pada limbah organik maupun anorganik dalam bentuk padat, cair, dan gas (Salt et al., 1998). Fitoremediasi dapat diterapkan pada lahan tercemar baik di perairan maupun daratan. Dibandingkan dengan teknik konvensional, maka teknik fitoremediasi dianggap sebagai teknik biaya rendah yang ditetapkan untuk area yang lebih luas (Pavanelli, 2019). Keuntungan lain dari fitoremediasi dibandingkan dengan teknik konvensional adalah gangguan rendah terhadap lingkungan, penerimaan publik, dan potensi untuk memulihkan berbagai polutan (Truua et.al 2015).

Implementasi fitoremediasi di lahan basah untuk pengolahan air limbah atau air tercemar yang berasal dari berbagai sumber memungkinkan menghilangkan polutan organik dan anorganik dari air dengan cara yang ramah lingkungan dan layak secara ekonomi. Saat ini, berbagai proses fitoremediasi di lahan basah kurang dipelajari dibandingkan dengan fitoremediasi tanah yang tercemar. Oleh karena itu diperlukan penelitian lebih lanjut untuk meningkatkan pemahaman tentang mekanisme penghilangan polutan dalam pengelolaan lahan basah dengan vegetasi, dan mendapatkan desain lahan basah dan parameter operasional untuk mencapai proses pengolahan yang lebih efisien (Truua et.al 2015)

Pada penerapan fitoremediasi ada beberapa persyaratan bagi tanaman yang akan digunakan. Menurut Youngman (1999) untuk menentukan tanaman yang dapat digunakan pada fitoremediasi dipilih tanaman yang mempunyai sifat: 1) Cepat tumbuh. 2) Mampu mengkonsumsi air dalam jumlah yang banyak pada waktu yang singkat. 3) Mampu meremediasi lebih dari satu polutan dan 4) Toleransi yang tinggi terhadap polutan. Banyak tanaman yang telah diteliti dan memperlihatkan kemampuan dalam meremediasi polutan seperti logam dan senyawa hidrophobik seperti BTEX (benzen, toluene, ethylbenzen dan Xylen), larutan klor, limbah amunisi, senyawa nitrogen dan cemaran hidrokarbon minyak bumi. Salah satu tanaman yang digunakan untuk fitoremediasi di lahan basah adalah tanaman keluarga Typhaceae seperti Typha latifolia dan Typha angustifolia. Tanaman tersebut telah diteliti dalam kemampuannya untuk membersihkan cemaran organik dan anorganik.

Penelitian pada tanaman Typha latifolia, menunjukkan setelah 120 hari terjadi degradasi TPH sebanyak 74\% di tanah yang bervegetasi dibandingkan 35\% di tanah yang tidak bervegetasi (Pavanelli, 2019). Tumbuhan tersebut juga mempunyai potensi untuk fitoremediasi logam berat $\mathrm{Hg}, \mathrm{As}, \mathrm{Pb}, \mathrm{Cu}$ dan $\mathrm{Zn}$ (Anning dan Akoto, 2018). Selanjutnya, penelitian aplikasi tanaman Typha angustifolia pada limbah organik industri kerupuk dengan sistem Subsurface Flow Constructed Wetland menunjukkan efisiensi penurunan konsentrasi yang paling baik pada 15 hari pengamatan dengan penurunan parameter total suspended solid (TSS) sebesar 84,71\%; BOD5 94,17\%; COD 94,87\%; Amoniak 87,52\%; Sulfida 99,81\% (Abdulgani dkk. 2014).

Pada pengolahan leachate tempat pembuangan akhir sampah (TPA) dengan salinitas tinggi, tanaman Typha angustifolia memiliki efektifitas 
lebih baik daripada Eichhornia crassipe (Niam dkk. 2013). T. angustifolia memiliki potensi tinggi sebagai tanaman untuk membersihkan tanah yang terkontaminasi logam berat timbal karena pertumbuhannya yang kuat, produktivitas biomassa yang tinggi, dan karena sifatnya yang abadi. $\mathrm{Di}$ tanah yang terkontaminasi dengan $266,7 \mathrm{mg} / \mathrm{kg}$ timbal, tanaman mengakumulasi 7492,6 $\mathrm{mg} \mathrm{Pb} / \mathrm{kg}$ berat kering di akar dan $167 \mathrm{mg} \mathrm{Pb} / \mathrm{kg}$ berat kering di daun. Namun dengan kadar timbal yang terdeteksi, tidak ada keterlambatan pertumbuhan tanaman (Panich-pat dkk. 2004). Selanjutnya penelitian campuran Typha angustifolia dan Eichornea crassipes mampu mengakumulasi logam berat seng, timbal dan cadmium dengan konsentrasi yang sama dalam akar dan tunas. Akumulasi logam berturutturut $\mathrm{Zn}>\mathrm{Cd}>\mathrm{Pb}$ (Sricoth dkk. 2018). Typha angustifolia juga mampu menurunkan $92 \%$ polutan logam tembaga dan nikel (Diaconu dkk 2019). Dari studi literatur menunjukkan bahwa tanaman Typha angustifolia mempunyai kemampuan dalam fitoremediasi logam berat dan limbah organik, namun penggunaan tanaman tersebut untuk fitoremediasi cemaran minyak bumi belum banyak dilakukan.

Oleh karena itu penelitian ini diarahkan untuk mengkaji potensi tumbuhan tersebut agar dapat diaplikasikan dalam fitoremediasi cemaran hidrokarbon minyak bumi di lahan basah. Sejauhmana adaptasi tumbuhan tersebut terhadap media yang tercemar hidrokarbon minyak bumi dan bagaimana kemampuan tumbuhan tersebut dalam menurunkan cemaran hidrokarbon minyak bumi, akan dibahas dalam makalah ini.

\section{BAHAN DAN METODE}

Hidrokarbon minyak bumi /minyak mentah (crude oil) diperoleh dari PT X di Kabupaten Siak Provinsi Riau. Tanaman air yang digunakan adalah tanaman lembang/tifa (Typha angustifolia) atau narrowleaf cattail, yang diperoleh dari lahan basah Kapuk Muara Jakarta Utara. Media tanam adalah lumpur yang diperoleh dari kawasan Puspiptek Serpong.

Sebelum percobaan dimulai dilakukan aklimatisasi terhadap tanaman tersebut dengan menanamnya dalam media lumpur sawah yang diberi pupuk kandang dan NPK selama sebulan, kemudian dilakukan seleksi tanaman yang akan digunakan. Pot yang digunakan berupa ember plastik yang diisi dengan $20 \mathrm{~kg}$ lumpur sawah dan diberi pupuk kandang 10\% serta ditanami dengan tanaman Typha angustifolia sebanyak 3 tanaman per pot. Media tumbuh ditambah dengan minyak mentah (crude oil) dengan beberapa konsentrasi yaitu $0,5 \mathrm{~kg}, 1 \mathrm{~kg}$ dan $2 \mathrm{~kg}$. Perlakuan masing-masing pot tersebut sebagai berikut :

- T0 = lumpur $+10 \%$ pupuk kandang + tanaman

- $\mathrm{T} 1$ = lumpur $+10 \%$ pupuk kandang $+0,5 \mathrm{~kg}$ minyak mentah + tanaman

- T2 = lumpur + 10\% pupuk kandang + $1 \mathrm{~kg}$ minyak mentah + tanaman

- T3 = lumpur $+10 \%$ pupuk kandang + $2 \mathrm{~kg}$ minyak mentah + tanaman Disiapkan juga pot dengan media yang sama dan konsentrasi minyak yang sama tetapi tanpa ditanami sebagai kontrol kontaminan.

Perlakuan kontrol tersebut sebagai berikut :

- K1 = lumpur + 10\% pupuk kandang $+0,5 \mathrm{~kg}$ minyak mentah 
- $\mathrm{K} 2$ = lumpur $+10 \%$ pupuk kandang $+1 \mathrm{~kg}$ minyak mentah

- $\mathrm{K} 3=$ lumpur $+10 \%$ pupuk kandang $+2 \mathrm{~kg}$ minyak mentah

Semua perlakuan baik perlakuan pot yang ditanami maupun yang tidak ditanami berjumlah tiga ulangan. Waktu pertumbuhan dilakukan selama 20 minggu. Parameter pertumbuhan yang diamati yaitu berat basah, panjang akar dan jumlah anakan yang diamati pada awal dan akhir percobaan dan pengamatan tinggi tanaman dilakukan setiap dua minggu. Pengamatan berat kering dilakukan pada akhir percobaan. Kadar bahan pencemar minyak yang dinyatakan dengan Total Petroleum Hydrocarbon (TPH) dianalisis pada awal dan akhir percobaan, dengan mengacu pada prosedur Solid Waste (SW) 846 metode 3540 dari U.S. Environmental Protection Agency (USEPA).

Data yang diperoleh dianalisis menggunakan Analisis Variansi (Anova) pada taraf kepercayaan 95\%. Jika hasil menunjukkan terdapat perbedaan diantara perlakuan, maka dilakukan uji beda nyata terkecil (BNT).

\section{HASIL DAN PEMBAHASAN}

\subsection{Pertumbuhan Tanaman}

Hasil penelitian menunjukkan bahwa tanaman Typha angustifolia dapat beradaptasi dan tumbuh pada media dengan penambahan minyak mentah pada kadar $0 \mathrm{~kg}, 0,5 \mathrm{~kg}, 1 \mathrm{~kg}$ dan $2 \mathrm{~kg}$. Namun demikian pada media dengan penambahan minyak mentah terjadi reduksi untuk semua parameter pertumbuhan yang diamati yaitu tinggi tanaman, panjang akar, jumlah tunas baru, dan biomasa segar dan kering, dimana pertumbuhan tanaman pada media kontrol (0 kg minyak) lebih baik dibandingkan pertumbuhan dalam media mengandung minyak. Semakin tinggi kadar minyak umumnya pertumbuhan tanaman semakin terhambat, hal ini mungkin disebabkan efek fitotoksisitas minyak mentah terhadap tanaman, seperti yang telah diteliti pada tanaman jagung dan kacang merah yang mengalami fitotoksisitas pada kadar minyak $10.000 \mathrm{mg} / \mathrm{Kg}$ minyak (1\%) (Baek, 2004). Menurut Khan (2000), tumbuhan mempunyai kemampuan untuk menahan substansi toksik dengan cara biokimia dan fisiologisnya serta menahan substansi non nutritif organik yang dilakukan pada permukaan akar. Bahan pencemar tersebut akan dimetabolisme atau diimobilisasi melalui sejumlah proses termasuk reaksi oksidasi, reduksi dan hidrolisa enzimatis. Oleh karena itu tanaman Typha angustifolia pada penelitian ini masih dapat tumbuh pada kondisi tanah yang tercemar oleh minyak bumi, walaupun mengalami hambatan pertumbuhan pada media yang mengandung minyak. Setelah penanaman 20 minggu, pengamatan parameter pertumbuhan vegetatif, baik secara visual maupun hasil pengukuran menunjukkan terjadi peningkatan pada semua parameter yaitu tinggi tanaman, jumah tunas, jumlah daun, panjang akar, dan berat biomasa tanaman. Untuk parameter tinggi tanaman, pertumbuhan pada media kontrol lebih tinggi dibandingkan media dengan penambahan minyak. Persentase peningkatan tinggi tanaman pada media kontrol yaitu sebesar $21,5 \%$, kemudian berturut-turut perlakuan minyak $0,5 \mathrm{~kg}$ yaitu sebesar $13,3 \%$, perlakuan minyak $1 \mathrm{~kg}$ sebesar $3,6 \%$ dan paling kecil peningkatannya 
adalah pada kadar minyak $2 \mathrm{~kg}$ yaitu sebesar $\quad 0,6 \%$. Parameter pertumbuhan tinggi tanaman menunjukkan terdapat perbedaan pada taraf kepercayaan $5 \%$. Uji beda nyata terkecil (BNT) menunjukan bahwa perlakuan minyak mentah $2 \mathrm{~kg}$ berbeda dengan perlakuan kontrol dan $0,5 \mathrm{~kg}$ minyak, namun tidak berbeda nyata dengan perlakuan $1 \mathrm{~kg}$ minyak.

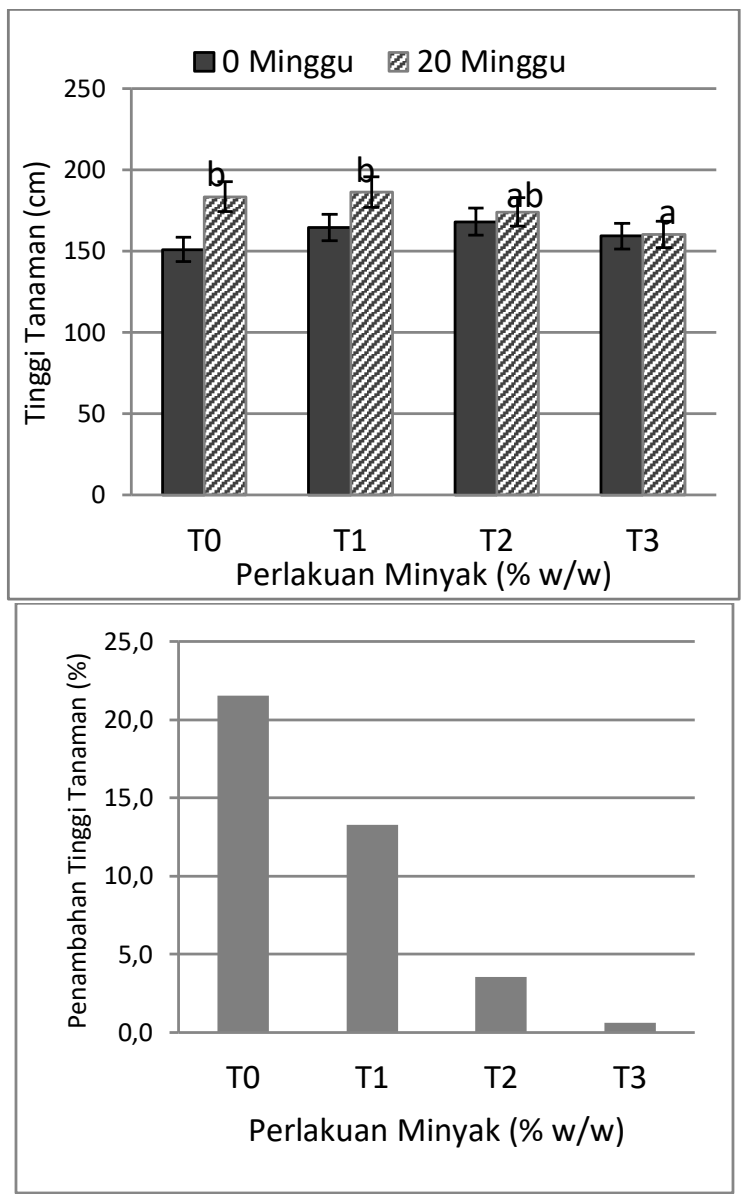

Gambar 1 Tinggi tanaman Typha angustifolia (kiri) dan persentase peningkatannya sampai pertumbuhan 20 minggu

Hasil analisis variansi panjang akar menunjukan tidak berbeda secara nyata pada taraf kepercayaan $5 \%$. Peningkatan pertumbuhan tertinggi dicapai oleh tanaman pada media kontrol $(134,4 \%)$, disusul oleh perlakuan minyak $1 \mathrm{~kg}$ (78,8\%), perlakuan minyak $1 \mathrm{~kg}(51,7 \%)$ dan perlakuan minyak $2 \mathrm{~kg}(-2,7 \%)$.
Perlakuan minyak $2 \mathrm{~kg}$ mengalami penurunan panjang akar karena sebagian akar mengalami gugur, pertumbuhan akar sangat terhambat, sehingga panjang akar tidak mengalami peningkatan. Hasil penelitian Milala et al. (2015) dan Umeh et al. (2017), mengamati bahwa keberadaan hidrokarbon yang 
berlebihan di lingkungan tanaman mempengaruhi transfer oksigen dan nutrisi karena menutupi akar dan poripori. Ini menyebabkan akar subpermukaan kekurangan udara terutama di tanah bertekstur halus (tanah liat) atau tanah dangkal dengan lapisan tanah kedap air. Akar berserat kecil kekurangan oksigen yang menyebabkan kematiannya. Secara keseluruhan, ini merusak sistem akar sehingga tidak dapat memasok air yang diperlukan untuk menggantikan yang ditransmisikan oleh daun. Hal ini menyebabkan kekurangan air sehingga menyebabkan layu dan / atau kematian tanaman (Rulley, 2019). Untuk mengetahui

perkembangan pertumbuhan tanaman secara lebih jelas dilakukan pengamatan parameter tinggi tunas baru setiap 2 minggu (gambar 2).
Pertumbuhan tinggi tanaman menunjukkan terus mengalami peningkatan pada semua perlakuan sampai pengamatan 20 minggu. Pertumbuhan tercepat terjadi pada umur 0 sampai 4 minggu pada semua perlakuan. Secara umum pertumbuhan tinggi tunas pada perlakuan $2 \mathrm{~kg}$ minyak lebih lambat dibandingkan tanaman pada perlakuan lainnya. Kondisi demikian kemungkinan karena tanaman pada perlakuan minyak $2 \mathrm{~kg}$ mengalami hambatan pertumbuhan karena efek fitotoksisitas cemaran minyak mentah terhadap tanaman. Pada umur 16 minggu pertumbuhan tinggi tanaman cenderung stabil atau tidak ada peningkatan. Kemungkinan tanaman sudah mencapai tinggi maksimum mulai umur 16 minggu.

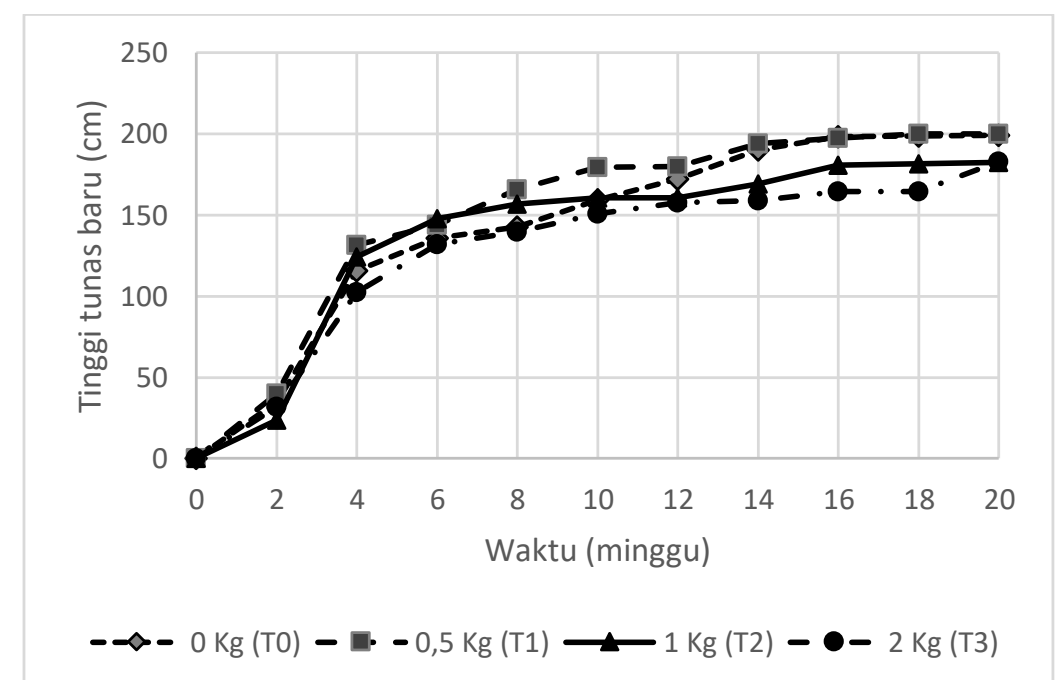

Gambar 2 Pertumbuhan tinggi tunas baru Typha angustifolia selama pertumbuhan 20 minggu. 


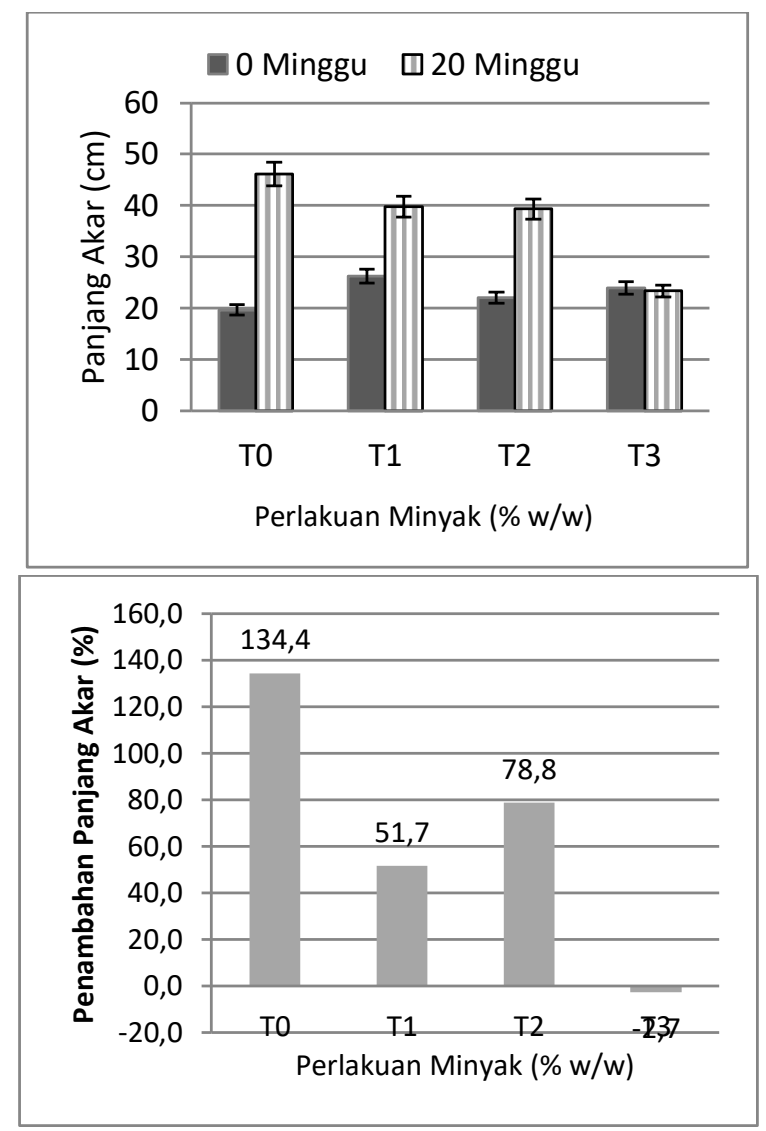

Gambar 3 Panjang akar Typha angustifolia yang ditanam dalam media mengandung minyak

Walaupun tanaman tifa minyak (kontrol) menunjukkan dipengaruhi oleh perlakuan minyak, penambahan jumlah tunas baru yang namun tanaman terus mengalami pertumbuhan. Hal ini dapat dilihat dari jumlah tunas yang terus mengalami peningkatan pada semua perlakuan minyak. Analisis variansi pada taraf kepercayaan $5 \%$, menunjukkan bahwa terdapat perbedaan yang signifikan diantara perlakuan minyak. Hasil uji beda nyata terkecil menunjukkan bahwa perlakuan yang berbeda adalah perlakuan minyak $2 \mathrm{~kg}$ dengan perlakuan lainnya. Perlakuan minyak 2 $\mathrm{kg}$ menunjukan jumlah tunas baru yang lebih sedikit daripada perlakuan lainnya sedangkan perlakuan $0 \mathrm{~kg}$ paling banyak. Dengan demikian minyak yang mencemari tanah berpengaruh terhadap pertumbuhan tanaman. Semakin besar kandungan bahan pencemar minyak semakin tinggi pengaruhnya terhadap pertumbuhan tanaman dan cenderung semakin menghambat pertumbuhan tanaman. Temuan ini juga didukung oleh Baruah et al. (2014) yang menyatakan bahwa biomassa tanaman berkurang dengan meningkatnya konsentrasi minyak mentah. 


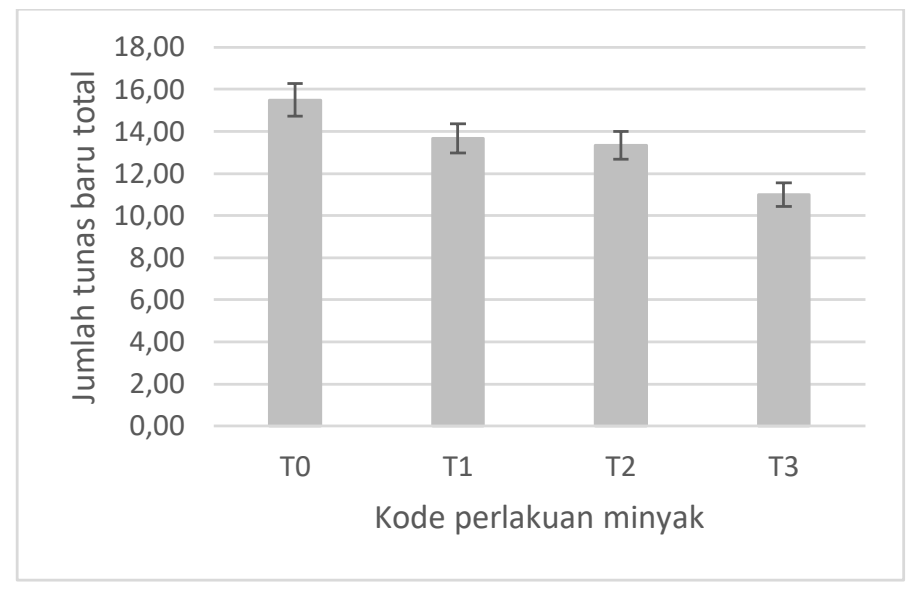

Gambar 4. Jumlah tunas baru tanaman Typha angustifolia sampai pertumbuhan 20 minggu.

\begin{tabular}{|c|c|}
\hline 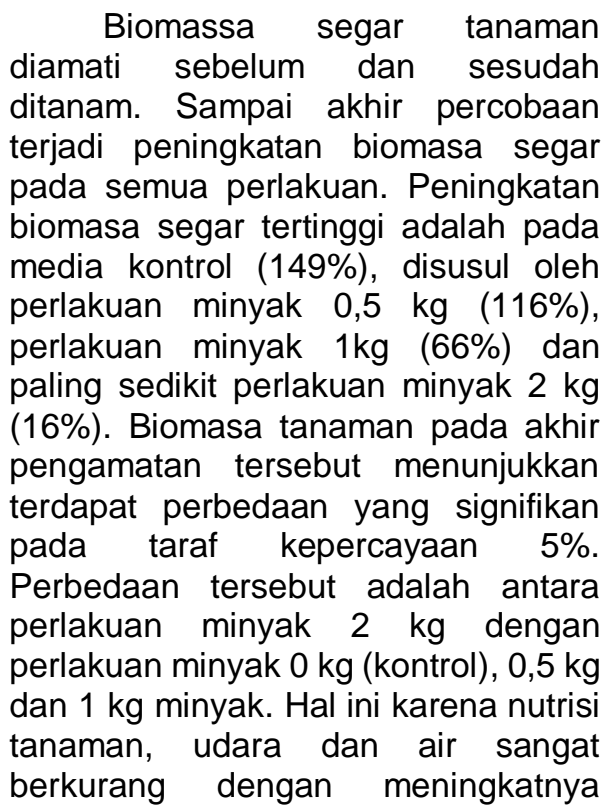 & buhan \\
\hline
\end{tabular}
konsentrasi TPH di tanah. Kekurangan 

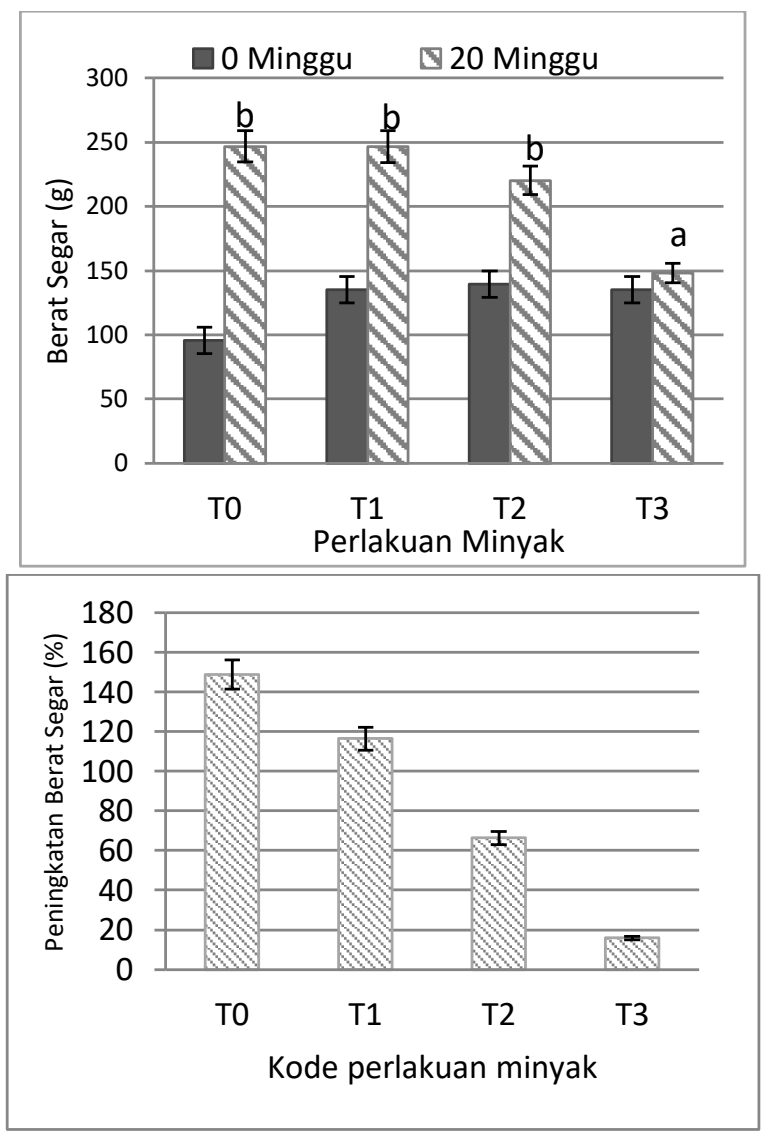

Gambar 5 Berat segar biomasa Typha angustifolia yang ditanam dalam media mengandung minyak

Pada akhir percobaan biomasa kering tanaman yang terbesar adalah pada media kontrol, dan disusul berturut-turut perlakuan $0,5 \mathrm{~kg}$ minyak, $1 \mathrm{~kg}$ minyak dan $2 \mathrm{~kg}$ minyak. Hasil analisis variansi menunjukkan bahwa terdapat perbedaan yang signifikan diantara perlakuan tersebut. Hasil perhitungan uji beda nyata terkecil (BNT) menunjukan terdapat perbedaan biomasa total antar perlakuan $2 \mathrm{~kg}$ minyak dengan perlakuan lainnya, dan antara perlakuan kontrol (0\%) minyak dibandingkan perlakuan lainnya, sedangkan perlakuan $0,5 \mathrm{~kg}$ dan $1 \mathrm{~kg}$ minyak menunjukkan tidak terdapat perbedaan biomasa yang siginifikan. 


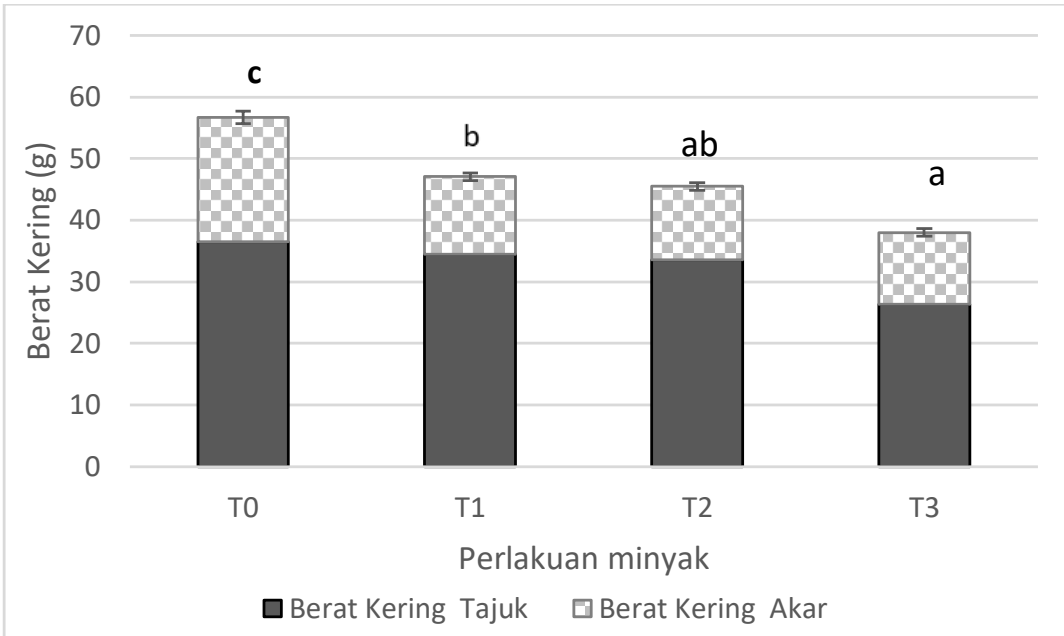

Gambar 6 Berat kering tajuk dan akar Typha angustifolia yang ditanam dalam media mengandung minyak bumi sampai pertumbuhan 20 minggu

Dari hasil penelitian tersebut menunjukkan bahwa perlakuan kontrol menunjukkan nilai rata-rata terbesar untuk biomassa tanaman, tinggi tanaman, jumlah tunas, dan panjang akar. Biomassa di bawah dan di atas tanah dalam hal total berat kering tanaman semuanya berkurang secara signifikan dengan meningkatnya konsentrasi minyak bila dibandingkan dengan kontrol. Temuan dari Wang et al. (2013) dan Ribeiro et al. (2014) membuktikan bahwa efek osmotik dari minyak mentah menciptakan kondisi yang tidak menguntungkan di tanah, sehingga menyebabkan tekanan air dan ketersediaan nutrisi yang terbatas bagi tanaman. Akibatnya, mengurangi biomassa tanaman secara keseluruhan. Temuan ini juga didukung oleh Baruah et al. (2014) yang menyatakan bahwa biomassa

tanaman berkurang dengan meningkatnya konsentrasi minyak mentah, yang dikaitkan dengan penurunan kandungan klorofil.

Selanjutnya rasio akar per tajuk yang tertinggi adalah pada perlakuan kontrol yaitu sebesar 0,55. Rasio akar / tajuk (Root / Shoot) adalah indeks penting untuk menilai kesehatan tanaman, dan sebagai indikator sensitif stres tanaman yang disebabkan oleh bahan kimia yang terdapat dalam tanah atau fisik tanah (Agathokloeous, E. 2019). Oleh karena itu sangat penting untuk memperhatikan kesehatan tanaman terutama akar, karena akar merupakan bagian yang kontak langsung dengan bahan pencemar seperti minyak bumi. 
Tabel 1 Rasio akar/tajuk tanaman Typha angustifolia yang ditanam dalam media mengandung minyak dan tanpa minyak pada pertumbuhan 20 minggu

\begin{tabular}{|c|c|c|c|}
\hline \multirow{2}{*}{$\begin{array}{c}\text { Konsentrasi } \\
\text { Minyak Bumi }\end{array}$} & \multicolumn{2}{|c|}{ Berat Kering $(\mathrm{g})$} & \multirow{2}{*}{$\begin{array}{c}\text { Rasio } \\
\text { Akar/Tajuk }\end{array}$} \\
\cline { 2 - 3 } & Tajuk & Akar & 0.55 \\
\hline $0 \mathrm{~kg}$ & 36.49 & 20.16 & 0.36 \\
\hline $0,5 \mathrm{~kg}$ & 34.5 & 12.57 & 0.35 \\
\hline $1 \mathrm{~kg}$ & 33.61 & 11.86 & 0.44 \\
\hline $2 \mathrm{~kg}$ & 26.39 & 11.63 & 0.5 \\
\hline
\end{tabular}

\subsection{Kadar Total Petroleum Hydrocarbon (TPH)}

Hasil analisis TPH sebelum dan sesudah penelitian baik pada media yang ditanami maupun tidak ditanami disajikan pada gambar 7 dan persentase penurunannnya disajikan dalam gambar 8. Hasil Analisa TPH pada minggu ke 20 menunjukkan kadar TPH yang lebih rendah daripada sebelum percobaan, baik pada media yang ditanami tanaman Typha angustifolia maupun media yang tidak ditanami. Hasil analisa TPH pada perlakuan yang ditanami lebih rendah daripada media yang tidak ditanami pada semua perlakuan. Dengan demikian penurunan kadar TPH pada perlakuan yang ditanami lebih besar daripada perlakuan tanpa ditanami. Penurunan TPH paling tinggi adalah pada perlakuan yang ditanami yang diberi minyak $0,5 \mathrm{~kg}$ (kandungan TPH awal $44.240 \mathrm{mg} / \mathrm{kg}$ atau 4,42\%). Penurunan TPH pada perlakuan tersebut sebesar $42,1 \%$, bandingkan dengan perlakuan media yang tidak ditanami dengan penambahan minyak yang sama yaitu $0,5 \mathrm{~kg}$ (kandungan TPH $43.360 \mathrm{mg} / \mathrm{kg}$ atau 4,34\%) menunjukkan penurunan TPH hanya $10,6 \%$. Pada perlakuan minyak $1 \mathrm{~kg}$ pada media yang ditanami juga menunjukan penurunan yang lebih besar yaitu $25,6 \%$ daripada tanpa ditanami yang hanya mampu menurunkan kadar TPH 10,1\%. Pada perlakuan minyak $2 \mathrm{~kg}$, tanaman juga mampu menurunkan kadar TPH, namun penurunannya tidak signifikan dibandingkan dengan perlakuan tanpa ditanami. Penelitian yang dilakukan oleh Pavanelli (2019), tanaman Typha latifolia mampu mendegradasi $\mathrm{TPH}$ sebesar $74 \%$ pada tanah yang ditanami, sedangkan pada tanah yang tidak ditanami hanya 35\% selama 120 hari masa tanam. Tanaman Ludwigia octavalvis yang ditanam dalam media yang berisi pasir dan lumpur minyak mentah (10\%, 50\%, dan 100\% (v/v)), degradasi lumpur minyak mentah (dinyatakan dengan kadar TPH) lebih tinggi pada media yang ditanami daripada media yang tidak ditanami (kontrol) selama paparan 42 hari (Alanbary et al. 2019). Hal ini menunjukkan bahwa keberadaan tanaman mampu menurunkan kandungan cemaran minyak, termasuk tanaman Typha angustifolia, sehingga tanaman ini potensial untuk digunakan dalam fitoremediasi cemaran hidrokarbon minyak bumi. 


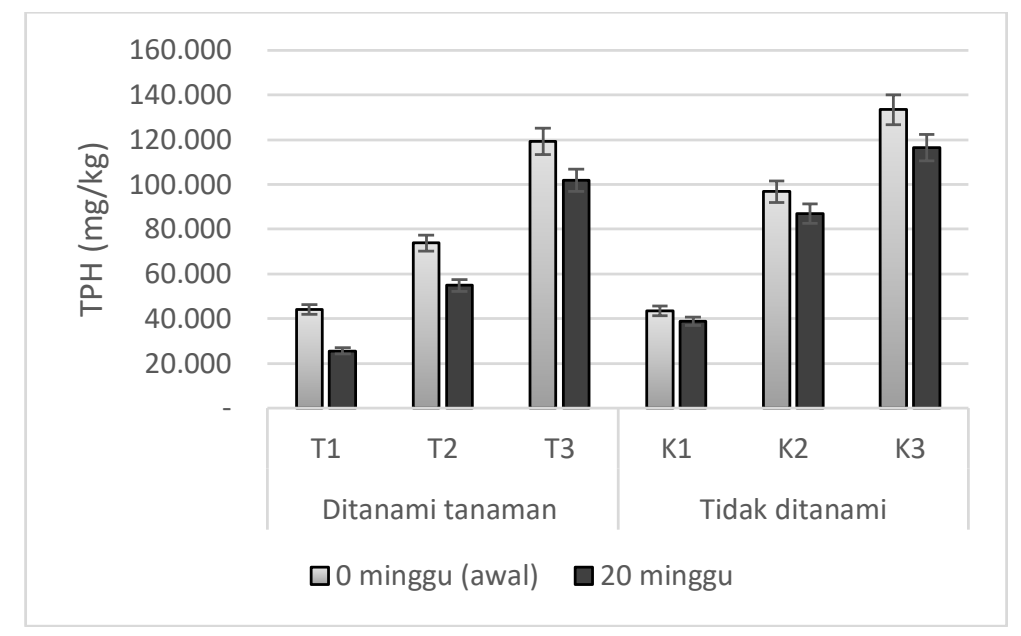

Gambar 7 Kadar TPH sebelum dan sesudah percobaan

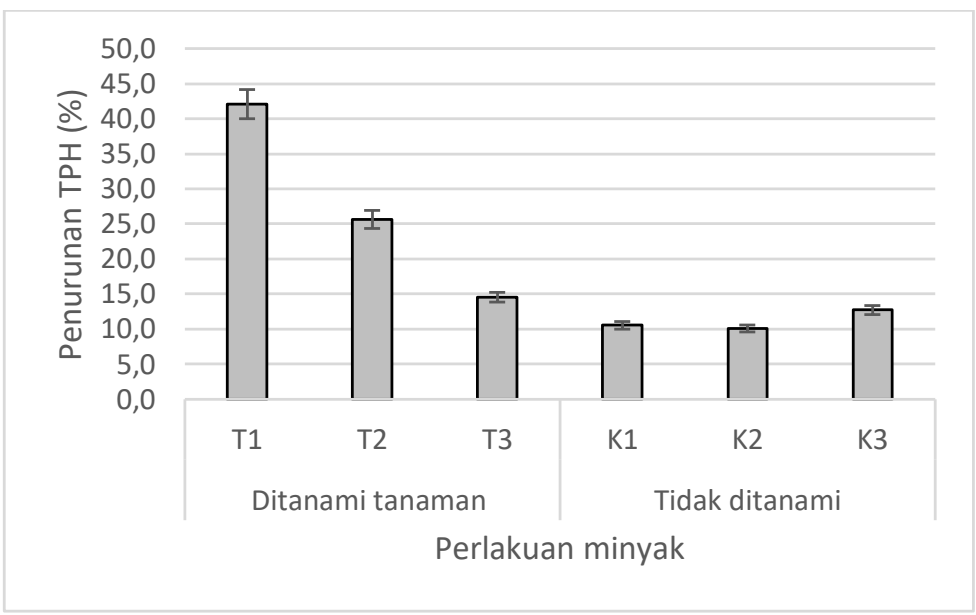

Gambar 8. Persentase penurunan TPH pada media yang ditanami tanaman Typha angustifolia dibandingkan dengan media tanpa ditanami tanaman tersebut sampai pengamatan 20 minggu

\section{KESIMPULAN}

Tanaman Typha angustifolia adalah tanaman lahan basah yang telah terbukti potensial untuk digunakan dalam fitoremediasi logam berat dan limbah organik domestik. Penelitian ini menyajikan potensi tanaman tersebut untuk fitoremediasi lahan basah yang tercemar oleh hidrokarbon minyak bumi. Dari hasil penelitian tersebut dapat disimpulkan sebagai berikut :

- Tanaman Typha angustifolia dapat beradaptasi dan tumbuh dalam media yang mengandung cemaran hidrokarbon minyak bumi pada konsentrasi TPH awal sampai 
$119.205 \mathrm{mg} / \mathrm{kg}$ atau $11,9 \%$ selama masa pertumbuhan 20 minggu.

- Pertumbuhan tanaman yang diamati dari biomasa kering tanaman menunjukkan pertumbuhan yang signifikan berbeda. Pertumbuhan tanaman tertinggi adalah pada media $0 \mathrm{~kg}$ (konrol) disusul oleh perlakuan minyak $0,5 \mathrm{~kg}, 1 \mathrm{~kg}$ dan paling rendah perlakuan minyak 2 $\mathrm{kg}$. Walaupun pertumbuhan tanaman pada media tanpa cemaran minyak bumi lebih tinggi, namun semua tanaman yang ditumbuhkan dalam media yang mengandung cemaran minyak juga terus mengalami peningkatan pertumbuhan yang diamati sampai pengamatan 20 minggu.

- Penurunan TPH pada semua perlakuan yang ditanami tanaman Typha angustifolia lebih besar dibandingkan dengan media tanpa ditanami tanaman tersebut. Persentase penurunan TPH tertinggi dicapai pada perlakuan minyak 0,5 $\mathrm{kg}$ (kadar TPH awal $44.240 \mathrm{mg} / \mathrm{kg}$ atau $4,42 \%$ ), dengan penurunan TPH sebesar $42,1 \%$.

- Dari hasil penelitian ini dapat disimpulkan bahwa tanaman Typha angusrifolia potensial untuk digunakan dalam fitoremediasi cemaran hidrokarbon minyak bumi.

\section{DAFTAR PUSTAKA}

Abdulgani, H., Izzati, M. dan Sudarmo, 2014. Kemampuan Tumbuhan Typha Angustifolia Dalam Sistem Subsurface Flow Constructed Wetland untuk Pengolahan Limbah Cair Industri Kerupuk (Studi Kasus Limbah Cair Sentra Industri Kerupuk Desa Kenanga
Kecamatan Sindang Kabupaten Indramayu Jawa Barat), BIOMA, Desember 2014 ISSN: 14108801 Vol. 16, No. 1, Hal. 90-101

Adipah, S., 2019. Introduction of Petroleum Hydrocarbons

Contaminants and its Human Effects, Journal of

Environmental Science and Public Health, Volume 3, Issue 1, 001-009.

Alanbary, SRN., Abdullah, SRS., AlBaldawi, IAW., Hassan, HA., Anuar, N., Othman, AR., Suja, F. (2019). Phytotoxicity of Contaminated Sand Containing Crude Oil Sludge on Ludwigia octovalvis, Journal of Ecological Engineering, Volume 20, Issue 11, December 2019, pages 246255

Anning AK and Akoto R., 2018. Assisted phytoremediation of heavy metal contaminated soil from a mined site with Typha latifolia and Chrysopogon zizanioides, Ecotoxicology and Environmental Safety, Volume 148, February 2018, Pages 97104

Anonim, Oil spill atau tumpahan minyak pengaruhnya terhadap lingkungan dan upaya penanggulangannya, http://mudahingat.com/oil-spillatau-tumpahan-minyak/ diakses tanggal 18 September 2019

Atlas, R.M., Bartha, R. 1992. Hydrocarbon biodegradation and oil spill bioremediation. In: (Marshall, K.C.) Advances in Microbial Ecology, 12. Plenum Press, New York, USA. Pp. 289338.

Baek KH, Kim HS, Oh HM, Yoon BD, Kim J, Lee IS. (2004). Effects of crude oil, oil components, and bioremediation on plant growth. $\mathrm{J}$ Environ Sci Health A Tox 
Hazard Subst Environ Eng. 2004;39(9):2465-72

Baruah P., Saikia R.R., Baruah P.P., Deka S. (2014): Effect of crude oil contamination on the chlorophyll content and morphoanat anatomy of Cyerus brevifolius (Rottb.) Hassk. Environmental Science and Pollution Research International, 21: 12530-12538.

Connel dan Miller, 1995, Kimia dan Etoksikologi Pencemaran, diterjemahkan oleh Yanti Koestoer, Penerbit Universitas Indonesia (UI Press), Jakarta

D.J. Glass, 1999, "US and International Markets for Phytoremediation 1999-2000", D. Glass Associates Inc., Needham-Massachussetts.

Diaconu, L., Butnariu, Cl., Catrina, AG., Parashiv, G., 2019. Water depollution using Typha angustifolia, International Journal of Engineering, Vol. 17 Issue 3, p199-200.

Evgenios Agathokleous, Regina G. Belz, Mitsutoshi Kitao, Takayoshi Koike, Edward J. Calabrese, 2019. Does the root to shoot ratio show a hormetic response to stress? An ecological and environmental perspective, Journal of Forestry Research. October 2019, Volume 30, Issue 5, pp 15691580

Eweis, J.B., Ergas, S.J., Chang, D.P.Y., \& Schroeder, E.D. (1998). Bioremediation Principles. Boston, McGraw-Hill. Khan, A.G., C. Kuek., Chaudrhry., C.S. Khoo \& W.J. Hayes. 2000. Role of Plant, Mycorrhizae and Phytochelator in Heavy Metal Contaminated

Land
Remediation. Chemosphere 41:197- 207

Melithia, C. L.A. Jhonson, Dan W. Amber. 1996. Ground Water Polution: In Situ Biodegradation. Down Loading, Available at http:www.Cee.Edu/ProgramAre as/Environmentaltetch/gw primer/Group 1/ind/ex/html.

Niam, AC.dan Warmadewanthi, I. 2013. Efektivitas Typha angustifolia dan Eichhorni crassipes dalam mengolah leachate dengan system contructed Wetland, Prosiding Seminar Nasional Manajemen Teknologi XVIII Program Studi MMT-ITS, Surabaya 27 Juli 2013

Panich-pat, T., Kruatrachue, M., Pokethitiyook, P., Upatham, S., 2004. Removal of Lead from Contaminated Soils by Typha Angustifolia, Water Air and Soil Pollution 155(1):159-171 · June 2004.

Pavanelli, AG. (2007), Phytoremediation of petroleum contaminated soil using Typha latifolia.

http://www.uel.br/pos/quimica/ar quivos/alex_pavanelli_abstract. pdf

Peraturan Pemerintah no. 101 tahun 2014 tentang Pengelolaan Limbah Bahan Berbahaya dan Beracun

Ribeiro H., Mucha A.P., Almeida C.M.R., Bordalo A.A. (2014): Potential of phytoremediation for the removal of petroleum hydrocarbons in contaminated salt marsh sediments. Journal of Environmental Management, 137: 10-15.

Ruley, JA., Tumuhairwe, JB., Amoding, A., Opolot, E., Origa, OO., and Basamba, T. 2019, 
Assessment of plants for phytoremediation of hydrocarbon-contaminated soils in the Sudd Wetland of South Sudan, Plant, Soil and Environment, 65, 2019 (9): 463469

Sari, E. 2014. Inventarisasi Tanaman Potensial Penyerap Limbah Cair Industri Rumah Tangga di Kecamatan Rumbai, Pekanbaru, Jurnal Pendidikan Biologi, Vol 1 No 2 (2014)

Sricoth, T., Meeinkuirt, W., Taeprayoon, P. Pichtel, J., Saengwilai, P. 2018. Synergistic phytoremediation of wastewater by two aquatic plants (Typha angustifolia and Eichhornia crassipes) and potential as biomass fuel, Environmental Science \& Pollution Research. Vol. 25, Issue 6, p5344-5358.

Truua, J., Truua, M., Espenberga, M., Nõlvaka, H., Juhanson, J., 2015. Phytoremediation and PlantAssisted Bioremediation in Soil and Treatment Wetlands: A Review, The Open Biotechnology Journal, 2015, 9, (Suppl 1-M9) 85-92

USEPA, 1999. Understanding Oil Spills And Oil Spill Response,
Office of Emergency and Remedial Respon, EPA 540-K99-007, diakses di https://www.epa.gov/sites/produ ction/files /201801/documents/ospguide99.pdf Wang Y., Feng J., Lin Q.X., Lyu X.G., Wang X.Y., Wang G.P. (2013): Effects of crude oil contamination on soil physical and chemical properties in Momoge wetland of China. Chinese Geographical Science, 23: 708-715

Youngman, L. 1999. Physiological respon Of Switchgrass (Panicum Virgatum L) to Organic And Inorganic Amened HeavyMetal Contaminated Chat Tailings. Phytoremediation of Soil and Water Contaminants, American Chemical society Symposium. Washington, D.C.

Onwurah, I. N. E., Ogugua, V. N., Onyike, N. B., Ochonogor, A. E. and Otitoju, O. F. (2007). Crude Oil Spills in the Environment, Effects and Some Innovative Clean-up Biotechnologies, International Journal of Environmental Research, Vol. 1, No. 4, 2007, pp.307-320. 